\title{
TASSO DA SILVEIRA E SEU ITINERÁRIO LUMINOSO
}

O. MARTINS GOMES

Para discorrer, embora sucintamente, sôbre a personalidade de Tasso da Silveira, com quem mantive amizade fraterna durante perto de sessenta anos, devo começar evocando os primórdios dêsse afetuoso convívio, ao desabrolhar de nossa juventude na terra natal de ambos.

A circunstância de residirmos do mesmo lado da então modesta cidade, na sua parte mais antiga, e, sobretudo, a vida estudantil, pois cursavamos igual série do Ginásio Paranaense, facilitaram essa aproximação. Muito mais, porém, do que tais fatôres, o interêsse por nós ambos revelado para as letras, notadamente a poesia, fortaleceu sobremaneira os elos de nossa união, naquela primeira fase.

Daí um passo para, juntamente com outro amigo do coração, de quem nos aproximaramos graças à ocorrência de análogas peculiaridades, - Lacerda Pinto, fundarmos, os três neófitos, um jornal literário, de publicação quinzenal - o Fanal, cujo primeiro número saiu a 15 de maio de 1911 , trazendo nossos nomes no cabeçalho e artigo de apresentação de minho lavra, de modo a justificar o aparecimento e o título.

Tasso, então com dezesseis anos, estampa tipogràficamente, e pela primeira vez, seus versos, um soneto em decassílabos, sob tema amoroso, cuja musa, entretanto, não era "Eleonora", evocativa do imortal homônimo, porém outra, de nome igual ao da inspiradora: também, de glorioso vate, proclamada repetidamente já de início: assim: "Ai! Minha Laura, minha Laura, certo / Teu fraco entendimento não alcança / Todo êste amor que, num botão aberto, / Está a florir em rútila esperança".

O jornal continuou a aparecer com regularidade, passando, a partir do quinto número, já em papel assetinado, a constituir "Órgão do Nôvo Cenáculo", com a participação ainda do jovem Colega José Guahyba (o prosador e sociólogo do grupo), mora- 
dor das mesmas bandas, e manteve igual feitura oté o número doze.

Animados com o pequeno sucesso publicitário, empreendemos a transformação da folho em revista, sob o mesmo nome, já em ano II, com o número 1 em fevereiro de 1912 e de aparecimento mensal, mas às vêzes atrazado, como costuma acontecer.

Seu último número data de dezembro de 1913, com índice alfabético dos trabalhos publicados nos dois anos, tudo formando um volume de 485 páginas.

Apresenta-se, pois, o Fanal como valioso documentário das atividades literárias do Paraná, nessa fase. Constituiamos nós redatores e os colaboradores Andrade Muricy, Leônidas de Loyola, Samuel Cesar, Acir Guimaräes, Savino Gasparini e outros, a geração denominada então "novíssima", para destacá-la da imediatamente anterior, os "novos", entre os quais figuravam Serafim França, Rodrigo Junior, Raul Gomes, Heitor Stockler, Francisco Leite e Clemente Ritz, e também da "antiga", abrangendo Emiliano Perneta, Emílio de Menezes, Nestor Victor, Leôncio Correia, Rocha Pombo, Dario Vellozo, Silveira Neto, Hugo Simas a Euclides Bandeira. De interêsse assinalar que aquela revista reunia a colaboração dos literatos das três mencionadas gerações.

Ozorio Duque Estrada, temível crítico da imprensa carioca, na sua coluna Registro Literário ("Correio da Manhä" de 18-2-1912), acolheu com entusiasmo o advento do Fanal, escrevendo: "A revista que tenho em mãos veiu confirmar de maneira surpreendente e decisiva as informações lisongeiras e repetidas que eu desde muito possuia acêrca da cultura cientifica e literária dos habitantes do Paraná, cujo maior centro intelectual, localizado na cidade de Curitiba, é um dos mais intensos e mais brilhantes de todo o Brasil. O número do Fanal, que acabo de receber, é um atestado vivo dessa verdade. Deparam-se-me aí composições de incontestável merecimento, firmadas tôdas por uma plêiade de poetas e prosadores de raça, do que muito se deve orgulhar aquele próspero Estado do sul."

Tasso da Silveira, afora algumas páginas em prosa, deu a conhecer no Fanal onze poesias suas, de composição variada, obedientes ainda à métrica e à rima, sob o influxo do parnasianismo e do simbolismo, das quais apenas reproduziu, no seu primeiro livro, o belo soneto Rei Destronado, com êste quarteto inicial: "Houve um tempo em que o mar, grandioso e soberano, / Sôbre a terra imperou... Nem valado, nem serra, / Nem animal, nem flor... Por tôda parte o insano / E trágico fragor que o seu rugido encerra."

Graciella Aédon, poetisa, de Nova Friburgo manifestou seu entusiasmo diante das primícias de Tasso, num poema de qua- 
tro sextilhas, do qual destaco êstes versos, prenunciadores de futuros remígios do jovem cantor: "Criança e vate: - pelo teu caminho / Irás tangendo a lira dos amores, / Irás cantando a Luz e a Liberdade..." (Fanal, n. ${ }^{\circ} 1$, pág. 11).

A existência instável de seu pai, Silveira Neto, o melancólico poeta do Luar de Inverno, servindo, na qualidade de funcionário da Fazenda Federal, em cidades diferentes e distantes, além de Curitiba e Paranaguá, ou sejam, Rio de Janeiro, Corumbá e Foz do Iguaçu, possibilitava frequentes viagens a Tasso. Naquela época de deficiência de comunicações, um percurso de Curitiba ao Rio de Janeiro durava três dias por mar e dois dias e meio por estrada de ferro. A Foz do Iguaçu e a Mato Grosso, o trajeto de ida, igual ao da volta, levava mais de um mês, primeiramente por mar, depois por via fluvial, subindo o rio da Prata e seus formadores Paraná e Paraguai. Ante essa referência e como nota marcante do progresso atual, é oportuno lembrar a recente inauguração do trecho final da rodovia asfaltada até Foz do Iguaçu, desde Paranaguá, permitindo seu trajeto de automóvel, do litoral àquele planalto, em cêrca de onze horas apenas.

Tasso passou o ano de 1910 no Rio, estudando no Colégio Pedro II: para lá transferido do Ginásio Paranaense, que voltou a cursar novamente em 1911 e em parte de 1912, pois em julho dêste ano foi novamente para o Rio. E na capital do país encetou, em 1913, seu estudo de Direito, na Faculdade Livre de Ciências Jurídicas e Sociais, voltando depois a Curitiba, onde então cursou a recém-fundada Faculdade de Direito da Universidade do Paraná, nos anos $2 .^{\circ}$ e $3 .^{\circ}$, retornando ao Rio em 1916. Nós outros seus amigos, Andrade Muricy, Leônidas de Loyola, Abel Assumpção e eu, que nos transferiramos no $5 .^{\circ}$ ano da Universidade do Paraná, devido a dificuldades no seu reconhecimento federal, para aquela Faculdade carioca, ali colámos grau com Tasso, a 14 de janeiro de 1919, em solenidade especial do grupo de paranaenses, tendo-se completado pois, recentemente, o cinquentenário de nossa formatura.

Tasso da Silveira, ainda jovem de vinte e um anos, capitalizando contactos anteriores, com colegas de cursos ali frequentados, entrou logo em comunhão com o meio intelectual do Rio de Janeiro. Conquanto poeta, visceralmente poeta, aprofundou o espírito em cultura onímoda, sobretudo filosófica, travando conhecimento com os luminares do pensamento, através dos tempos. Seu primeiro livro, sob o título Jackson de Figueiredo, com 37 páginas, publicado no Rio em 1916, mostra já a feição de ensaista, mais acentuada em livros posteriores, sem prejuízo de copiosa e magnífica produção em verso, através de tôda a sua nobre vida. 
Nềsse estudo sôbre o jovem intelectual sergipano e aindo em tôrno de figuras de relêvo de outros Estados, como Farias Brito, Xavier Marques e Garcia Rosa, o nosso Tasso lança esta observação: "Nêste país, em que, por sôbre a enorme deficiência de meios de comunicoção entre os Estados, há uma inacreditável incúria por tudo o que se faz nos fundos obscuros da província, torna-se necessário que os menos indiferentes empreendam uma cruzada santa em prol do alevantamento do nome daqueles que jazem esquecidos ou até incógnitos, embora com tanto mérito como os que mais o possuam, só porque não se valeram de nossas avenidas e livrarias para o exalçamento de sua glória. O Rio de Janeiro precisa saber que mesmo longe de sua vida tumultuária florescem grandes almas". (pág. 17). E adiante: "O Rio de Janeiro, essa grande caixa de ressonância, como já o qualificou alguém, faz repercutir pelo Brosil tôdas as vozes que no seu seio se levantam". E a seguir: "Transportado definitivamente para a capital brasileira, Jackson de Figueiredo sentiu alargarem-se-lhe os horizontes". (pág. 21).

Em verdade, o Rio de Janeiro exerceu sempre êsse fascínio nos intelectuais novéis. E não foi sem assinalados proveitos que vultos da geração "antiga" de literatos paranaenses, ou sejam Emiliano Perneta, Emilio de Menezes, Leoncio Correia, Nestor Victor, Silveira Neto e Rocha Pombo, procuraram a saturação dêsse máximo ambiente para conseguir as vantagens assinaladas. E Dario Vellozo, de lá vindo aos 16 anos, já trazia no espírito certa sedimentação cultural do meio em que até então vivera.

Tal alargamento de horizontes produz-se comumente com a convivência em ambientes mais avançados nos domínios da cultura, inclusive graças ao bom funcionamento de cursos superiores. Isso ocorria ainda mais antigamente, até o primeiro quarteirão dêste século, em face do atrazo de meios de comunicação, não só para transporte material, como para transmissão de mensagens: sem estradas suficientes, sem aviação, sem rádio, com cinema ainda mudo e incipiente e, sobretudo, sem televisão - essa maravilha moderna que projeta dentro de nossos lares, em imagem e som, no mesmo instante, tudo o que ocorre na terra e também, agora, na lua...

Guerra Junqueiro, poeta e pensador português, lá pelos idos de 1910 acentuava, com pasmo, como das maiores conquistas da ciência, poder o pensamento humano, através do cabo submarino, dar a volta à terra em 24 horas...

Em 1918, no Rio, Tasso publica seu primeiro livro de versos, sob a modesto denominação de Fio d'Água, contendo 33 poesias, das quais esta, no pórtico: 
Fio d'água, humilde e brando,

Da transparência dos cristais:

Tão claro e límpido vais

Cantarolando,

Que deixas ver, lá, no fundo,

A areia fina alvejando...

Tão diáfano! até parece

Que a areia é que vai cantando...

Verso meu, fio d'água oriundo

Da fonte da dor... pudesse

(Ai de mim!)

Fazer-te tão claro assim,

Que se visse, lá no fundo,

- só - minha alma cantando

ou soluçando...

E prossegue ininterruptamente, naquela metrópole, a atividade intelectual de Tasso, com predominância da produção poética, mas variando paro o ensáio, a crítica, a pregação cívica, o romance, o teatro, o ensino em cátedra de literatura, as conferências, os cursos de extensão, as traduções de famosos autores, a polêmica, a colaboração na imprensa periódica, tendo pertencido ao corpo de redação de alguns jornais. No nosso grupo, fundou em Curitiba a revista Athenéia, em 1914. E no Rio de Janeiro as revistas América Latina, Terra de Sol e Festa.

Mais tarde se pôs à frente da revista de grande sucesso "Cadernos da Hora Presente", com a cooperação de Rui de Arruda.

Seu livro Romain Rolland, em 1919, foi distinguido com Menção Honrosa, em concurso da Academia Brasileira de Letras. Em 1921 publicou Dario Vellozo, perfil espiritual do saudoso mestre da mocidade paranaense e cujo centenário de nascimento transcorre nêste ano.

Em 1922 reuniu em volume, sob o título de A Egreja Silenciosa, aqueles ensáios, acrescidos de outros sôbre Cruz e Souza, Emiliano Perneta, Euzebio Mota, Nestor Victor, Adelino Magalhães, Augusto dos Anjos, Farias Brito e mais escritores, bem assim abordando temas de arte e filosofia.

Com o espírito cada vez mais aclarado por fôrça de progressivos estudos e leituras, toma incremento sua produção poética, em novos rumos, quanto à concepção dos assuntos e mesmo á forma. E dá à publicidade: A Alma Heróica dos Homens, em 1924; Alegorias do Homem Novo, em 1926; As Imagens Acesas, em 1928; Cântico ao Cristo do Corcovado, em 1931; Discurso ao Povo Infiel, em 1933; O Canto Absoluto e Alegria do 
Mundo, em 1940; Cantos do Campo de Batalha, em 1945; Contemplação do Eterno, em 1952; Puro Canto, em 1956; Regresso à Origem, em 1960. Nessa série inclui-se a coletânea de poemas escolhidos intitulado Descobrimento da Vida, em 1936.

Muitas de suas poesias foram traduzidas para outras línguas ou musicadas por compositores de nomeada, como Camargo Guarnieri, Lorenzo Fernandez e Brazílio Itiberê, êste paranaense.

Nascido em 1895 em Curitiba, na antiga rua do Assungui (hoje Mateus Leme) porque levava a um sitio distante, dêsse nome, esquina da rua Barão de Antonina, ali passou sua primeira infância. E no decorrer da vida, sofrendo os embates da cidade tumultuosa, no Rio, êle recordou, tocado de profunda saudade, aquele aspecto de sua meninice, nêste poema:

\section{RUA DO ASSUNGUI}

Eu vou pela avenida ampla e longa, e iluminada, em que há palácios e torres e cúpolas de ouro erguidas como as de velha estampa da infância iluminada, como as de velha estampa que tanto me fêz sonhar!

Eu vou pela avenida longa, mas vou indiferente...

Porque no êxtase dos mens olhos, como numa água morta, uma beleza mágica outrora se refletiu...

Oh, não foi como esta, uma ampla avenida cheia de palácios, tôrres, cúpolas. Mas uma rua de Aldeia com a luz de um lampeão morrente...

- Que são estas luzes vivas da avenida resplandecente perto daquele lampião,

que iluminava até o fundo - grande abismo profundo da minha imaginação?!... 
E a minha ruela humilde

era mais longa... ia além...

Quando a noite se adensava

perdia-se ela na sombra,

na sombra longa, infinita,

muito longe, para além,

... de onde eu, trêmulo, esperava

as coisas que nunca vêm...

O escritor Joaquim Ribeiro, em seu livro Itinerário Lírico de Tasso da Silveira (Rio, 1939, 80 págs.) assim apreciou o talento poético do cantor: "Não faz Tasso da Silveira poesia filosófica. Nem poesia religiosa. Apenas sua poesia revela raízes de pensamento filosófico e sentimento religioso. Essas raízes, todavia, acham-se dentro da terra poética; são como que veias ocultas, que buscam seiva, mas, por se acharem mergulhadas subterrâneamente, mal se adivinham".

Extraordinária se patenteou sempre a persistência de Tasso, na sua ânsia de cultura, na sua vocação de escritor, na sua fidelidade aos magnos ideais que abraçou. Jackson de Figueiredo, acatado pensador católico, seu contemporâneo e amigo, prematuramente falecido em acidente, assim sucintamente definiu Tasso: "A mais séria, a mais heróica, a mais resistente das almas da geração a que pertenço".

Alguns moços do nosso grupo em Curitiba transferimos também residência para o Rio de Janeiro, em 1916 e 1917: Andrade Muricy, outro nome eminente nas duas atividades de sua preferência - a crítica literária e a crítica musical, com ensáios correlatos, as quais lhe valeram, entre outros galardões, a alta posição, hoje, de membro do Conselho Federal de Cultura (Câmara de Artes) e seu vice-presidente; Abel Assunção, mais ligado ao Estado do Rio, onde desempenhou relevantes funções públicas; Brazilio Itiberê, que se destacou no ensino superior da arte musical e como compositor de música moderna; e eu, que ali permaneci durante dez anos, trabalhando em cargos públicos, até que regressei à terra natal para dedicar-me, com gôsto, à advocacia militante, mister em que, entre outros, melhor me realizei. Lacerda Pinto fêz todo o curso de Direito em São Paulo, na sua tradicional Faculdade.

Tasso era de uma operosidade heróica. Si vivia para o pensamento e para o belo, com os olhos fitos no céu, empenhava-se, com os pés em terra, na luta material para defender o pão nosso de cada dia.

De família pobre, seu pai percebia vencimentos que só davam para manutenção do lar modesto, com a esposa, muitos filhos e o sogro doente. Nos primeiros lustros de sua existência 
no Rio, Tasso, quer solteiro, quer já casado, morava em bairros distantes, na zona norte, donde o percurso até o centro, ou de regresso para casa, se fazia em bonde elétrico ou de trem suburbono, pois ainda não estavam em uso os utilissimos ônibus. Cada viagem dessa durava uma hora aproximadamente. A desvantagem da demora e do desconfôrto se mostrava entretanto compensada com a possibilidade de leitura aos pasageiros que assim queriam aproveitar o tempo. Os bondes eram mais pesados e mais sacolejantes do que os ônibus sôbre o asfalto, e também de mais ruído, devido ao atrito com os trilhos de ferro. Frequente observar professôres, jornalistas, homens de letras e estudantes, absorvidos na leitura e de lapis à mão nêsses longos trajetos. Tosso mesmo me confessou o quanto os aproveitava para saciar sua sêde de saber, saboreando livros ou compondo versos mentalmente, durante a longa travessia.

Tasso casou-se em 1920 com sua prima Noemi Albuquerque da Silveira, que lhe foi dedicadíssima, mas faleceu oito anos antes dêle. Causou-lhe enorme falta a esposa, que, nos últimos anos antes de morrer, acompanhava o marido nos cursos em que ministrava oulos de literatura, jó com a vista quase totalmente perdida, por motivo de doença. Dêsse consórcio lhe advieram as filhas Maria Lígia, Maria Helena, Maria Lúcia, Maria da Glória e Maria Raquel e os filhos Mario Marcos e Mario Cesar. Crudelíssimo the foi o golpe sofrido com a perdo da primeira, aos 13 anos de idade. Filhas e filhos cresceram e, por sua vez, se casaram, advindo-lhe dai mais dois graus de descendentes, pois Tasso, ao falecer, contava 18 netos e 2 bisnetos.

Seu idealismo, sua tenacidade, sua fidelidade à missão cultural de que se sentia ungido eram admiráveis e desafiavam mesmo sua resistência física. Naquela batalha duríssima para manter a família, com afetuosa dedicação, nunca esmoreceu um só dia, em meio de sérias dificuldades, nas tarefas ligadas à sua produção intelectual. Seus livros sobem a mais de 50 volumes, dos quais mencionarei ainda outros, além dos já indicados. $E$ mereceram iconceitos elogiosos de penas autorizadas, como se verá.

Mario de Andrade, de São Paulo, escreveu:..."o artista, além de fazer grande poesia, como se deu por destino criar, alcança também as alturas do grande poeta. Eu não sei nem me interessa saber qual a posição que tomará futuramente, na poesia contemporânea do Brasil, o claro e belo poeta do Canto Absoluto".

Adonias Filho, em seu livro crítico Tasso da Silveira e o Poema da Poesia Eterna (S. Paulo, 1940), observa: "A sua missão é essa. E Tasso da Silveira procurou realizá-la quase heróicamente, compreendendo talvez que a poesia sempre castiga os poetas traidores, os que se vendem ao gôsto do público. Assim, 
isolado na suá guerra, submisso à sua vocação, Tasso da Silveira penetrou na poesia eterna e fez do seu tema o tema da sua poesia".

Eugênio Gomes, de Belo Horizonte, manifesta o "profundo contentamento de encontrar (na obra de Tasso) a poesia em seu mais puro estado". E acrescenta: "Coisa rarissima nêstes tempos ! Não creio que a herança do simbolismo já houvesse produzido entre nós um rendimento assim tão rico de quinta-essência e de beleza formal. Regresso à Origem revela a mais pura nota de ternura humana que a sua poesia já tenha desferido, porque acrescida de um leve tom nostálgico, que jamais resvala para a aflição, o que representa um alto triunfo espiritual".

Eis, dêsse volume, êste poema de suavidade e fé, comunicando a sensação do momento extremo, nos limites entre a vida e a morte:

\section{FRONTEIRA}

Há o silêncio das estradas

e o silêncio das estrêlas

e um canto de ave, tão branco,

tão branco, que se diria

também ser puro silêncio.

Não vem mensagem do vento,

nem ressonâncias longínquas

de passos passando vão.

Há um pôrto de águas paradas

e um barco tão solitário, que se esqueceu de existir.

Hó uma lembrança do mundo mas tão distante e suspensa...

Há uma saudade da vida porém tão perdida e vaga, e há a espera, a infinita espera, a espera quase presença da mão de puro mistério que tomará minha mão e me levará sonhando para além dêste silêncio, para além desta aflição.

Em 1955, Tasso presta homenagem à terra natal com a coletânea de poesias antes divulgadas, sob o título Canções a Curitiba, trazendo no pórtico esta dedicatória: "A Curitiba, a cidade adolescente, dos céus profundos e das colinas suaves, e das árvores longas, - pela ânsia de pureza e pela graça luminosa que pôs na minha vida e na minha alma". 
Tasso, ao condensar a sua produção poética de mais de quarenta anos, em vez de "antologia", preferiu reuní-la em um só volume, de 388 páginas e cêrca de 320 poemas, sob o expressivo título de um de seus livros, Puro Canto (Edições GRD, 1962, Rio), trozendo na capa autorizados juizos críticos de escritores nacionais e estrangeiros, alguns já aqui mencionados.

Lacerda Pinto, nosso amigo comum, em carta tornada pública, assim a inicia, a propósito dêsse auspicioso surgimento: "Nesta altura da vida brasileira, o acontecimento desta publicação não é apenas um ponto de incalculável significado para as letras do Brasil e, em particular, para a vida do Paraná intelectual: êste livro é a suma dos sonhos que a nossa geração viveu e o marco capital da longa caminhada que a sua alma relizou, por entre rosas e abrolhos, sem esmorecer nunca, para afirmação do seu ideal de beleza e da sua confiança na vitória do espírito". (D. do P., Ct., 7-3-63).

Na bibliografia sôbre Tasso, além dos volumes já aludidos, um de Joaquim Ribeiro, outro de Adonias Filho, há a registrar mais dois: Tasso da Silveira - o Poeta e o Romancista, de Amándio Cesar (Rio, 1958, 55 págs.) e Tasso da Silveira e seu Universo Poético, de Leodegario $A$. de Azevedo Filho, tese de concurso para a cátedra de português e literatura do Colégio Pedro II (Rio, 1963, 253 págs.).

A propósito daquela primeira obra, estudando não só o poeta, como o romancista, registre-se que foram três os romances que Tasso publicou: Só tu Voltaste? (243 págs.) em 1941; Silêncio (268 págs.) em 1946, e Sombras no Cáos (322 págs.) em 1960.

Avultada se apresenta a produção de Tasso nos domínios da crítica literária, social e filosófica, a saber: Gil Vicente e outros Estudos Portuguêses (223 págs.) em 1940; Tendências do Pensamento Contemporâneo (1 87 págs.) em 1935; Estado Corporativo (301 págs.) em 1937. Ainda: estudos sôbre Euclides da Cunha, Gandhi, Cruz e Souza e outros, reunidos nos volumes 30 Espíritos Fantes (249 págs.) em 1937; Alegria Criadora (302 págs.) em 1928; Caminhos do Espírito (222 págs.) em 1937; Literatura Comparada (135 págs.) em 1964.

Espírito combativo, não se esquivava à polêmica. Negou primazia à renovação da arte poética no Brasil tendo como marco mais significativo a "Semana de arte moderna" no capital paulista, em 1922. E lançou ardorosos artigos defendendo a concomitância, quando não a prioridade do grupo do Rio de Janeiro, do qual foi êle o maior animador, dando origem à revista Festa, com Andrade Muricy, Cecilia Meirelles, Murilo Araujo, Adelino Magalhães e outros. Daí o surgimento, mais tarde, do livro Definição do Modernismo Brasileiro (128 págs.) de grande formato, em 1932. 
Econômicamente sofreu alternativas, mas nunca possuiu bens estáveis e rendimento que não fôsse de seu próprio esfôrço. Depois de aposentado como alto funcionário da Casa da Moeda, continuou exercendo a cátedra universitária de literatura em várias escolas superiores do Rio de Janeiro. Há cêrca de doze anos adoeceu gravemente $e$, em consequência, chegou quase a perder - sentido da visão, tanto que, para ler e escrever, passou a necessitar, de então para cá, da ajuda de outrem, primeiro sua devotada espôsa e, depois, suas filhas, netas e alunas dedicadas. Tal situação penosa provocou a generosidade dos conterrâneos de Tasso. Na sua exuberância de bondade e de dinamismo altruista, Raul Gomes movimentou a Assembléia Legislativa e a Câmara de Vereadores, conseguindo que ambas essas entidades votassem ajuda pecuniária a Tasso, em quota mensal, de alguma valia na época, embora depois se fôsse tornando cada vez menos útil, em face da notória depreciação da moeda, decorrente do fenômeno inflacionário. Mas, Tasso, com sua capacidade de inteligência, veiu a superar a crise e, quando faleceu, embora sem bens de raiz, a não ser modesta casa em Cabo Frio, oara repouso às vêzes, desfrutava bons proventos mensais de várias aposentadorias, de acôrdo com as necessidades atuais, conquanto. a final, algumas economias reunidas fôssem abrangidas e ultrapassadas, ultimamente, pelos pesados gastos hospitalares, na tentativa de sobreviver à pertinaz doença.

O Paraná com frequência tributava a Tasso atenções por êle sempre merecidas. Foi muitas vêzes recebido e festejado em suas agremiações literárias, notadamente a Academia Paranaense de Letras, na qual tomou posse em sessão solene de outubro de 1947 , quando, por agradável coincidência, me achava eu na sua presidência, sendo êle saudado por Lacerda Pinto, em erudito discurso de apreciação crítica à obra do poeta (Rev. da Acad. P. de L., n. ${ }^{\circ}$ 13. pág. 10). Na primeira República, o saudoso chefe político dr. Afonso Camarao incluiu o nome de Tasso da Silveira na relação para deputados estaduais pelo partido dominante (P.R.P.) e êle foi eleito, exercendo o mandato de 1928 a 1930.

Idealista, profundamente patriota, jamais indiferente aos magnos problemas da humanidade e do Brasil, embora livre-pensador na juventude, tornou-se depois católico convicto e devotado às práticas religiosas, como terceiro franciscano. Da sua doesia ressumbra elevação mística e ânsia de libertação espiritual. Como bem disse Adonias Filho, "penetrou na poesia eterna e fez do seu tema o tema da sua poesia". A propósito, acabo de ler sério estudo de Reynaldo Bairão, sob o título "Breve panorama da poesia brasileira contemporânea. Da Semana de arte moderna aos concretistas", com esta concisa referência: "Tasso da Silveira publicou diversos livros de poemas, entre êles: "Alegorias do Homem Novo" e "Contemplação do Eterno", ambos de fran- 
cas tendências místicas; "(Supl. Lit. ${ }^{\circ}$ de "O Est. de S. Paulo" de 20 de setembro de 1969).

Foi companheiro de Plinio Salgado na campanha integralista, em repressão ao surto comunista, sendo apresentada naquela oportunidade, pelo partido, sua candidatura a senador pelo Paraná, quando conseguiu apreciável votação, não bastante entretanto para eleger-se.

Honrosas láureas, prêmios e galardões conquistou, sendo de maior relêvo "O Prêmio Machado de Assis" que, pelo conjunto da obra, Ihe conferiu, em 1956, a Academia Brasileira de Letras, a móxima distinção que a prestigiosa instituição concede anualmente. Com tantos méritos comprovadamente proclamados, no entanto não chegou Tasso a ingressar na mencionada Academia, embora a ela se houvesse candidatado em certa ocasiāo, retirando porém logo suo candidatura. $E^{\prime}$ de notar, com extranheza que, depois de Emilio de Menezes e Rocha Pombo, nenhum escritor paranaense ingressou mais naquele alto cenáculo, durante os quarenta e seis anos decorridos.

Ao completar 70 anos, a 5 de março de 1965, o acontecimento mereceu a celebração de seus amigos e admiradores. 0 "Jornal do Comércio" do Rio, em edição de 14 dêsse mês, dedicou à efeméride duas páginas. com a fotografia, em ponto grande, de Tasso, nove poemas de sua lavra e artigos de Andrade Muricy (biografia e bibliografia), Luiz Delgado, Murilo Araujo, Mello Cançado, Pádua de Almeida, Leodegário A. de Azevedo Filho, Adelino Magalhães e Frederico Carvalho. O fato repercutiu jubilosamente em Curitiba, com publicidade pela imprensa e envio de mensagens congratulatórias. Luiz Delgado, da Bahia, escreveu: "Lá está, com efeito, nessas últimas coletâneas de versos de Tasso da Silveira, aquela beleza intensa e clara, tão vibrante de sentimento quão despojada de qualquer ornato, que não a sua total e perfeita expressividade, que há de ter sido o sonho de tôdas as horas de seu nobre coração". Quero ilustrar o valioso conceito, dando abaixo esta poesia, reminiscência ainda da infância de Tasso:

\section{O POÇO}

O poço estreito e profundo

é que era o centro do mundo.

Havia outras coisas mais:

a cêrca de ripa tosca,

além da cêrca o banhado, onde as räs, em tom magoado, cantavem na noite fôsca velhas contigas irreais: 


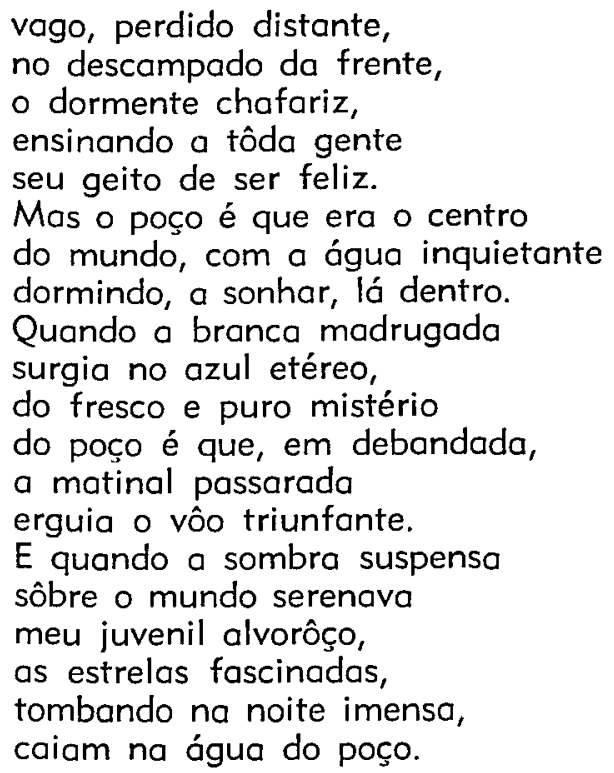

De Alceu Amoroso Lima: "A grande, a inefável beleza, a nobre música dêstes poemas - que vêm coroar tôda uma vida e tôda uma obra dedicadas ao incessante amor e à procura incançável dessa fugidia Beleza, que tudo prepara para a eternidade nêste mundo de coisas efêmeras em que vivemos, - é bem o alto complemento de tôda essa obra e de tôda essa vida". (Puro Canto, 1962, capa).

Antonio Olinto, crítico literário $\mathrm{d}^{\prime \prime} \mathrm{O}$ Globo", em sua importante seção "Porta de Livraria", teceu preciosos comentários ao livro de Tasso sôbre Literatura Comparada, assim concluindo: "Literatura Comparada", de Tasso da Silveira, surge num momento de crise crítica em nossa literatura, quando ninguém se planta, com vontade de trabalhar e de pesquisar, no terreno que dêsse sacrifício - e que sacrifício é — tanto precisa. Poderá êsse poeta, que também é crítico, fazer muito bem a esta nossa fase de carência aferidora. Sua posição nas letras brasileiras de símbolo de um tempo de fidelidade a um ofício e de exemplo de existencialidade literária — é das que têm por estôfo a duração". (N. ${ }^{\circ}$ de 13-3-65).

Não apegado a qualquer escola literária, o poeta adota as mais variadas formas de expressão, ora procurando a essência do seu pensamento, pela síntese, pelo símbolo, ora através da descrição singela, de efeitos simples na aparência mas profundos no conceito. Transbordante de imagens belas, palmilha as altas sendas da espiritualidade, por vêzes sugerindo ao leitor solenes ambientes litúrgicos. Vai da perfeição parnasiana à quase abstração dos modernistas, passando pelo simbolismo, sob cuja 
influência iniciou suas experiências literárias. Não importa a classificação, mas sim o alto teor da mensagem poética que Tasso nos legou, como um R. M. Rilke, no Europa, um W. Whitman, na América, um R. Tagore, na Ásia.

$E$ à alusão a poetas extranhos, quero acrescentar a referência a um brasileiro, para afirmar que são comparáveis aos sonetos de amor de O. Bilac os 41 "Sonetos antigos" de Tasso (Puro Canto, 1962, pág. 329).

Na valiosa colecão "Panorama da Poesia Brasileira" (Edit. Civil Bras.), o vol. V, ao tratar do "Pre-Modernismo", entregue à alta competência de Fernando Góes, traz no prefácio esta observaçāo: "Período Sincretista, como lhe chamou Tasso da Silveira; Nacionalista ou Eclético, na definição de Alceu Amoroso Lima; Intervalar, segundo Waltensir Dutra e Fausto Cunha; NeoRomântico, como: no dizer de alguns contemporâneos, constatou Múcio Leão, a época literária que se situa entre o início do século e a eclosão da Semana de Arte Moderna, em 1922, parece que, embora impròpriamente, encontrou o nome definitivo para caracterizá-la: Pré-Modernismo, consoante o denominaram também Alceu Amoroso Lima e Mário da Silva Brito".

Ante a variedade da produção poética de Tasso, seu enquadramento nas efêmeras corentes literórias varia. Talvez fique mais bem definido como um neo-simbolista, surgido no assinalado período, si se quizer colocá-lo num molde mais estrito. Mas, ante a variedade assinalada. êle é mais sincretista ou eclético. E si Fernando Góes, no aludido volume, não o inclui entre os "premodernistas", entretanto Mário da Silva Brito, com a responsabilidade de apresentar o volume $V I$ daquela coleção, relativo a "O Modernismo", aprecia à sua maneira Tasso e o inclui entre os "Modernistas", reproduzindo-lhe três poemas, entre os quais êste:

\section{A CRUZ}

Das mãos do Senhor erguiam-se labarêdas, dos Dés do Senhor erguiam-se labarêdas, dos flancos do Senhor erguiam-se labarêdas, de dor...

O corpo divino se estorcia como um tronco verde na queimada.

O incêndio de dor crepitava violento em tôda a carne do Senhor.

$E$ as mãos que tinham abençoado infinitamente eram agora folhas crestadas, e os pés que tinham sogrado os caminhos do mundo eram rebentos retorcidos, e a cabeça que abrigava os pensamentos eternos era uma fronde que ia tombar reboando. 
O incêndio de dor crepitava violento

na alma e na carne do Senhor.

$E$ as chagas eram brasas vivas,

e as palavras que brotavam trêmulas

dos lábios que haviam pronunciado as verdades divinas

eram outras chamas, mais altas e puras,

de dor infinita.

$O$ incêndio de dor crepitava violento

e enchia do seu rumor imenso

a grande noite

do mundo...

Na lira polimorfa de Tasso, o soneto desfruta igualmente de alta sonoridade. Não obstante sua forma clássica, êle suaviza a rijeza parnasiana, compondo o verso espontânєo, fluente e cantante. Se o abstracionismo e mesmo o concretismo dos modernos encontra larga onda de admiradores que compreendem e aplaudem a arte nova, o leitor comum, de boa compreensão literária, ainda se dessedenta nas belezas da poesia de forma rítmica e rima. Aí está Olavo Bilac, o poeta preferido das mais cultas camadas sociais do Brasil, com cêrca de trinta edições, só pela Livraria Francisco Alves, do livro Poesias, publicado pela primeira vez há oitenta anos, mais tarde acrescido de novas produções que, contudo, não aumentaram o brilho e o sucesso da primeira edição, quanto à qualidade.

Tratando-se de versos de amor, Bilac é inexcedível no desembaraço com que aborda o tema, temperando-o de sabor voluptuoso e beleza poética.

O grande poeta, solteiro, boêmio, desinibido, canta a variedade de suas sensações, como naquele lindo soneto "Última página", em que, em cada estação do ano, êle mudava de amada: "Primavera... Doirava o sol de outubro a areia dos caminhos (Lembras-te, Rosa ) e ao sol de outubro nos amámos". - "Verão. (Lembras-te, Dulce ?) À beira-mar sòsinhos, tentou-nos o pecado: olhaste-me e pecamos". E foi Laura, no outono, Branca no inverno. E conclui nêste terceto: "Carne, que queres mais? Coração, que mais queres? / Passam as estaçõee e passam as mulheres... / E eu tenho amado tanto? e não conheço o Amor!"

Constitui êsse um setor delicado que abordo agora, passageiramente, apenas, em tôrno de alguns aspectos da atitude de Tasso através de seus versos.

Católico sincero, ao publicar seu primeiro livro, em 1918, ali se lê o soneto "Carne", com êste final:

"Carne, que matarás o sonho que me exalta!

Negra barreira a erguer-se, intransponível, alta no caminho lustral da minha Redenção..." 
Noivo nessa época, veiu a casar dai a dois anos. Amou sempre profundamente sua mulher e dedicou-lhe inúmeros poemas, entre os quais destaco, pela sua grandiosidade, esta pequenina "Canção" (P. C., p. 173):

"Es a totalmente amada

e a totalmente desejada, porque és a que Deus me deu.

És a que perpetuou a adolescência em minha vida, e a que pôs em meu destino passageirc.

um frémito de eternidiade..."

Seus sonetos se alinham, incontestòvelmente entre os mais belos da lingua portuguesa, dentro do eterno tema. $O$ poeta sentiu novas emoçōes, através de sua vida, que não foi curta, transcorrendo, em certa fase, na viuvez.

Dos "Sonetos Antigos", para aqui traslado dois:

\section{XII}

Como escutas a voz do meu chamado?

$\mathrm{E}^{\prime}$ em puro sonho que te chamo, e vens...

Chamo-te ansiado, desesperançado, tão do segredo de mim mesmo, e vens...

Sou píncoro sombrio e atormentado, és ove de céus límpidos. E vens... Nem bem teu nome eu tenha pronunciado numa surdina de êxtase, tu vens...

Vens, e não sabes para que vieste, nem como vieste e que atração profunda, que secreto condão te trouxe a mim.

Mas de luz meu ser todo se reveste. E a alegria arcangélica me inunda, E a divina harmonia canta em mim.

\section{XIV}

"Teu nome feito para velhos pergaminhos..."

Este verso de Mallarmé, quizera-o meu, paro dizê-lo à que, pelos rumos mesquinhos, de minha vida, em ouro e luz, me apareceu.

A que um nome assim tem, feito de luar e arminhos, Nome preclaro de Rainha no apogeu, ou de pálida irmã que, entre rosas e espinhos, num convento medievo um dia adormeceu. 
Nome, no entanto, que eu de maneira nenhuma poderia gravar em terrena matéria, que tenho de esconder, de submergir em mim.

Pois a que amo é a Proibida. É sonho, estrêla, espuma. É a Proibida. E só Deus, na alta mansão etérea, Só Deus me perdoará de tê-la amado assim.

No primeiro soneto acima, êle fugiu à regra antiga de rimar três vêzes o sequndo verso do primeiro quarteto. E repetiu sempre a mesma palavra "vens", com talento e perícia, como mestre no seu artezanato. Assim como não procurou rima para o último verso e repetiu "mim".

Aprecie-se agora, no segundo soneto, como o poeta evoluiu em discreção e reserva, depois daquele primeiro soneto da adolescência, mencionado no início dêste artigo - "Ai! Minha Laura, minha Laura..." Para pesquizar o nome assim cuidadosamente ocultado teriamos agora de rebuscar arquivos de um convento medieval, ou talvez, mais pròximamente, procurar a história da rainha-mãe de Portugal, no começo do século...

Tasso, nos últimos anos, viajava com frequência, sempre acombanhado de uma neta dedicada, de modo a suprir-lhe as deficiências de visão. Proferia conferências em Belo Horizonte, onde contava muitos amigos e admiradores. Visitava Curitiba, alqumas vêzes hosoedando-se comigo. Em 1965, a convite do Debartamento de Educacão da Faculdade de Filosofia da Universidade do Paraná, ministrou no seu anfiteatro, durante duas semanas, um curso de extensão sôbre "análise literária exaustiva". Em 1967 acompanhou a urna com os restos mortais de seu pai, Silveira Neto, trazida do Rio de Janeiro, para ser inumada sob o pedestal do monumento em bronze que a cidade de Morretes erigiu ao cantar das Margens do Nhundiaquara, como homenagem póstuma de sua terra natal.

Tasso, ao falecer. deixou ainda vários volumes inéditos, principalmente estudos críticos, entre os quais um livro sôbre o grande poeta portuauês Antonio Correia de Oliveira, que êle teve a satisfação ainda de visitar pessoalmente em sua quinta ao norte de Portugal, auando para lá viajou com sua mulher, convidado a proferir conferências literárias. Êsses inéditos, entre os quais figuram ainda peças para teatro, com sugestivos títulos, foram entreaues por sua família ao nosso comum amigo Andrade $\mathrm{Mu}$ ricy. $E^{\prime}$ mais um acêrvo precioso que fica sob a guarda cuidadosa e idônea dêsse escritor paranaense, além de arquivos semelhantes de Cruz e Souza, Nestor Victor, Rocha Pombo, Silveira Neto, Henrique Abílio, José Silva Muricy e Moysés Marcondes. Incançável na pesquisa crítica, acha-se em vias de sair a segunda edição, revista e ampliada, do monumental "Panorama do Movi- 
mento Simbolista Brasileiro", de Andrade Muricy, publicado em 1962 pelo Instituto Nacional do Livro do Ministério de Educação e Cultura, em três volumes.

Senti relativa satisfação de me encontrar ao lado de Tasso nos últimos dias de sua vida, bloqueada pelo mal que the foi reduzindo a resistência durante três mêses, até falecer a 3 de dezembro de 1968, aos 73 anos de idade. No seu enterramento, coube-me proferir, à beira do túmulo, palavras de despedida em nome do Estado do Paraná e de suas entidades culturais, notadamente a Academia Paranaense de Letras, que o homenageou ainda com uma coroo. Os principais jornais cariocas estamparam, nos dias seguintes, destacadas noticias sôbre o triste evento, que repercutiu ainda, atrovés de oradores e votos de pezar, na Câmara dos Deputados, na Academia Brasileira de Letras, no Conselho Federal de Culturo, em estabelecimentos de ensino e outras entidades às quais o escritor e professor servira ou pertencia. Dias decorridos, extensos e honrosos panegíricos apareceram nos jornais do Rio de Janeiro, São Paulo, Belo Horizonte, Recife e Curitiba, assinados por Tristão de Athayde (Alceu Amoroso Lima), Plínio Salgado, Miranda Neto, Antonio Olinto, Luiz Delgado e outros. Coube-me traçar o elogio de Tasso nas sessões especiais que the dedicaram a Academia Paranaense de Letras e o Instituto Neo-Pitagórico. E foi já dado o nome de "Tasso da Silveira" a um ginásio estadual situado em Curitiba, no bairro Pilarzinho. Como homenagem póstuma de alta expressão, merece registro a prestada por valoroso grupo de intelectuais de Minas Gerais, através de três páginas do suplemento literário do "Jornal do Comércio" do Rio, de 6 de abril de 1969. A par da reprodução de cinco poemas de Tasso, ali estāo estampados artigos de apreciação devidos às penas de A. A. de Mello Cançado, João Etienne Filho, Alfredo Leite e Duílio Gomes. E o "Jornal das Letras", do Rio, no seu número de maio seguinte, insere belíssima página evocativa de Lacerda Pinto. E no número de junho trouxe excelente estudo de Luiz Delgado, do Recife, sob o título "O Poeto Morto", do qual destaco êste trecho: "Não o bafejou algumas dessas brisas benéficas que, ora justa, ora injustamente, enchem as velas de certos barcos e os levam pelos mares da fama. Entre os méritos de Tasso da Silveira e o conhecimento do seu nome ocorria - sobretudo nos últimos tempos - certo desajuste que não nos honra. Êle era um poeta digno de figurar e figurava, de fato, na galeria dos Manuel Bandeira e Carlos Drummond. A série dos seus "Sonetos Antigos" é uma das coisas mais intensas e límpidas, mais perfeitas, de tôda a lírica que já se verteu na língua de Camōes".

Miranda Neto, no seu "Folhetim do Jornal do Comércio" (Rio, 8-12-68), que publica semanalmente, ocupa-o todo a propósito do passamento de Tasso, com os seguintes períodos, entre 
outros: "Era êle o vate, no sentido mais alto e mais nobre da palavra, sacerdote e profeta. Por isso mesmo, ao abordar o real não começa a analisá-lo, como fazem tantos poetas modernos; não se deixa dominar por êle. Antes o subjuga, com a fôrça da intuição, o insere em uma totalidade, nêle totalmente condicionada por uma visão cristã do mundo". (. . . .) "Não teve grandes honras, no mundo, o poeto Tasso da Silveira. Pobre viveu e pobre morreu, sem fardōes e sem veneras, sem prebendas, dessas com que o poder costuma premiar os turiferários".

Destaco, em nota abaixo, dois trechos do artigo noticioso e erudito do ilustre parlamentar e escritor Plinio Salgado, por motivo da morte de Tasso e sua repercussão na Câmara dos Deputados ("O Jornal" do Rio, de 18-12-68), onde the coube o principal discurso. (1)

$E^{\prime}$ - me dado o prazer, ao terminar o presente trabalho, de verificar ainda as justas comemorações que a passagem do primeiro aniversário do desaparecimento de Tasso suscitou, notadamente no Rio de Janeiro. Assim é que, pela Rádio do Ministério da Educação e Cultura, coube ao eminente poeta Carlos Drummond de Andrade proferir uma palestra a respeito.

(1) Assim começo Plinio Solgado:

Faleceu há dias, na Guanabara, o poeta e escritor Tasso da Silveira. Sendo filho do Paraná, a bancada daquele Estado na Cámara Federal requereu à Mesa fôsse dedicado o grande expediente da sessäo de têrça-feira desta semana à homenagem póstumo ao coestoduano ilustre. Subscrevi também o requerimento, nāo só pela particular amizade por mim dedicada ao poeta, que foi também meu companheiro de lutas pela renovação política do Brosil, mas ainda pela minha vinculaçōo à terra paranaense, através de ascendêncio genealógica, mais tarde fortalecida com a espetacular votação do Estado à minha candidatura à presidência da República. Em sinal de gratidāo, representei o Paraná durante uma legislatura e vindo depois à Câmara pelo meu Estodo, nunca deixei de tomar parte nas legítimas reivindicaçōes daquela unidade da Federação.

"Na sessão memorativa, fui à tribuno e procurei fixar a posição e significação de Tasso nas letras brasileiras. Para recortar o seu perfil, tive de ir òs raizes do movimento literário ao qual estêve ligado: o simbolismo".

E adiante: "Atinge a plenitude do seu estro em 1940, com os livros "O canto absoluto" e "Alegria do mundo". Em 1945 produz os "Cantos do campo de batalha". A transcendência de sua inspiração dita-lhe em 1952 a "Contemplação do eterno" e, como quem atinge o cume do montanha, pelo aperfeiçoomento espiritual, pelo sotrimento, pela conquista das formas poéticas definitivas, publica "Puro canto".

A importância dêste livro revela-se no fato de ter escolhido o seu título para enfeixar a produção poética de tôda a sua vida, no volume editado por RGD, sob a direção do seu discípulo, que lhe dedicava amor filial, Gumercindo Rocha Dórea". 
E "O Globo" estampou cuidadosa rememoraçẩo em meia página, com artístico retrato do poeta e ampla informação sôbre sua obra, aos cuidados de Frederico de Carvalho (2).

Finalizo relembrando estas palavras de Frei Clarêncio Neotti, que o visitava no leito de sofrimento, com frequência: "Tasso mostrava certo mêdo da morte. "Ajude-me a enfrentar o mistério" - me suplicou um dia, depois da Comunhão. Era o mistério da morte. $E$, antes de morrer, passou quase dez dias em coma profundo, como que recolhido para compor o grande poema do encontro com Deus". ("Jornal do Comércio", Rio, 20-5-69).

E Tasso bem o previra, naqueles versos de "Fronteira", já aludidos:

$$
\begin{aligned}
& \text {..."a espera, a infinita espera, } \\
& \text { a espera quase presença } \\
& \text { da mão de puro mistério } \\
& \text { que tomará minha mão } \\
& \text { e me levará sonhando } \\
& \text { para além dêste silêncio, } \\
& \text { para além desta aflição..." }
\end{aligned}
$$

(2) O título d" "O Globo", em 3 colunas, é - "1 ano sem Tasso da Silveira", seguido desto monchete: "Depois de um longo período de sofrimento, morria na madrugada de 3 de dezembro do ano passado o poeta, ensaista, romancista, dramaturgo, professor catedrático de literatura e estética em três universidades, prêmio Machado de Assis da Academia Brasileira de Letras e lider de umo das focçōes em que se dividiu o movimento modernista Tasso da Silveira".

Transcreve depois muitas opiniões elogiosas sôbre o poeto, entre outras já aqui mencionodas, de Augusto Frederico Schmidt, Menotti del Picchia, José Geraldo Vieiro, Agripino Grieco, Nestor Victor, Joāo Ribeiro e Andrade Muricy. Fornece longa listo das obras de Tasso, nos seus variados gêneros - poesia, ensáios, romance, teatro, didática, traduçōes, prefácios e poemas musicados.

E assim termina Frederico de Carvalho: "Outro obra importonte, que se projeta publicar em Portugal, é o estudo exegético do poesia de Antônio Correia d'Oliveira. O próprio Tasso considerova-o o mais exaustivo exercicio de interpretaçāo estético global que realizoro, utilizondo todo o instrumental de anólise que êle mesmo ajudou a formular durante os muitos anos de ensino da literotura, além da sua próprio experiêncio pessoal amadurecida no trato da poesia duronte umo vida inteira.

- Homem pobre, cheio de filhos, a vida inteira êle lutou com grande dificuldade para sustentar a familio, ocumulando inclusive empregos subalternos. Não obstante, sua fidelidade à literatura é impressionante. Com todos èsses encargos, escreveu e publicou a numerosa obra aqui assinalada. Era um esceto por instinto, pois seu amor pelos coisas simples e essenciais fazio-o escapar sem esfôrço ao jugo pesado da sociedade de consumo. E era o poesia em pessoa, como o chamou Melo Cançado. Vivia em permanente estado de poesia, tronsformondo tudo, amôres, alegrias, sofrimentos, em expressão poética, vivida ou escrita".

- Tocou-me receber, ainda, recentemente, uma separata do revista portuguèsa OCIDENTE, de Lisboa (vol. LXXVII, de 1969, contendo sucinto artigo sôbre a vida e a obra de Tasso, devido à erudita pena de Leodegario $A$. de Azevedo Filho, autor já do substoncioso estudo exegético "Tasso da Silveira e seu Universo Poético", atrós mencionodo. 